\title{
ANALISIS EFISIENSI ALOKATIF PENGGUNAAN FAKTOR-FAKTOR PRODUKSI PADA USAHATANI JAGUNG (Zea mays L.) (Studi Kasus di Desa Dengkol, Kecamatan Singosari, Kabupaten Malang)
}

\author{
ALLOCATIVE EFFICIENCY ANALYSIS OF PRODUCTION FACTORS \\ USAGE IN MAIZE (Zea mays L.) FARMING \\ (Case Study in Dengkol Village, Singosari District, Malang Regency)
}

\author{
Anugerah Wibishanna $^{1 *}$, Moch. Muslich Mustadjab ${ }^{2}$
}

Jurusan Sosial Ekonomi, Fakultas Pertanian, Universitas Brawijaya, Jl. Veteran Malang 65145, Indonesia

Received: 26th October 2015; Revised: 10th March 2016; Accepted:10th March 2016

\begin{abstract}
ABSTRAK
Jagung merupakan komoditas pangan strategis di Indonesia sehingga usahatani jagung seharusnya memberikan pendapatan yang tinggi bagi petani. Pendapatan usahatani dapat ditingkatkan jika penggunaan faktor - faktor produksi efisien. Tujuan penelitian ini adalah untuk menganalisis sejauh mana tingkat efisiensi alokatif penggunaan faktor - faktor produksi pada usahatani jagung berpengaruh terhadap tingkat pendapatan petani. Dengan menggunakan analisis fungsi produksi dan analisis regresi berganda diperoleh kesimpulan bahwa penggunaan faktor - faktor produksi dalam usahatani jagung semuanya tidak efisien, sehingga juga belum dapat disimpulkan seberapa jauh pengaruh tingkat efisiensi terhadap pendapatan usahatani. Oleh sebab itu, diperlukan penelitian lebih lanjut berkaitan dengan pengaruh tingkat efisiensi terhadap pendapatan usahatani dengan sampel yang lebih besar.
\end{abstract}

Kata Kunci : Jagung; pendapatan; efisiensi

\begin{abstract}
Maize is strategic crops commodity in Indonesia so that maize farming should provide high income for farmer. Farming income can be improved if the use of production factors is efficient. The objective of the research is to analyze how far the level of allocative efficiency of the use of production factors in maize farming affect on the level of farmers income. By using production function and multiple regression analysis concluded that the use of all production factors were inefficient, so it also could not be concluded how far the effect of the efficiency level on the maize farming income. Therefore, further researches is needed relating to the effect of efficiency level on the farm income with larger sample size.
\end{abstract}

Keywords : Maize; income; efficiency

\section{Pendahuluan}

Pertanian merupakan sebuah sektor utama dalam kehidupan di Indonesia. Sektor pertanian sampai sekarang masih tetap memegang peran penting dan strategis dalam perekonomian nasional. Berdasarkan data BPS $\left(2015^{\mathrm{a}}\right)$, terdapat sebanyak 40 juta masyarakat Indonesia bekerja di bidang pertanian. Selain itu, sektor pertanian juga menjadi penyedia bahan baku untuk sektor industri, serta penghasil devisa dari ekspor.

\footnotetext{
"Penulis Korespondensi.

E-mail: wibishanna@gmail.com

Telp: +6285213507172
}

Jagung merupakan komoditas tanaman pangan yang memiliki peranan penting dan strategis setelah padi dalam pembangunan nasional. Posisi strategis Indonesia yang beriklim tropis dan memiliki tanah yang subur dan laut yang luas, membuat Indonesia dapat digolongkan sebagai negara agraris maritim serta selayaknya menempatkan produk pertanian dan kelautan sebagai kekuatan utama, salah satu produk pertanian yang seharusnya bisa dikembangkan adalah jagung (Kemendag, 2012).

Provinsi Jawa timur merupakan provinsi sebagai produsen jagung pangan terbesar di Indonesia 2014 dengan nilai produksi sebesar 5.737.382 ton yang diikuti oleh provinsi Jawa 
Tengah dengan nilai produksi sebesar 3.051.516 ton dan provinsi Lampung dengan nilai produksi sebesar 1.719.900 ton di urutan ketiga (BPS, $2015^{\text {b }}$ ). Kabupaten Malang merupakan kabupaten dengan produksi jagung terbesar ke tujuh di Jawa Timur. Salah satu desa potensial tanaman jagung pangan di Kabupaten Malang adalah Desa Dengkol. Penduduk di Desa Dengkol rata - rata bermata pencaharian sebagai petani tanaman pangan diantaranya adalah jagung, padi dan tebu. Jagung yang dibudidayakan petani di Desa Dengkol tersebut merupakan jagung hibrida. Desa Dengkol merupakan desa potensi jagung pangan di Kabupaten Malang yang sudah lebih dari 25 tahun lalu. Benih hibrida yang digunakan memungkinkan untuk mendapatkan hasil produksi sebesar 8-12 ton/ha. Benih hibrida ini seharusnya dapat memberikan penerimaan yang lebih besar mengingat potensinya.

Berdasarkan uraian diatas, masalah penelitian dapat dirumuskan sebagai "Sejauh mana tingkat efisiensi alokatif penggunaan faktor-faktor produksi jagung yang dicapai petani berpengaruh pada tingkat pendapatan usahataninya" maka tujuan dilakukannya penelitian ini adalah (1) Menganalisis efisiensi alokatif penggunaan faktor - faktor produksi pada usahatani jagung di daerah penelitian, (2) Menganalisis tingkat produksi dan pendapatan petani pada usahatani jagung di daerah penelitian, (3) Menganalisis faktor-faktor yang berpengaruh pada produksi dan pendapatan usahatani jagung di daerah penelitian, (4) Menganalisis pengaruh tingkat efisiensi yang dicapai petani terhadap tingkat pendapatan usahatani jagung di daerah penelitian.

\section{Metode Penelitian}

Penelitian ini dilaksanakan di Desa Dengkol Kecamatan Singosari Kabupaten Malang, Provinsi Jawa Timur. Penentuan lokasi ini dilakukan secara purposive yang didasarkan pada Desa Dengkol tersebut merupakan salah satu desa yang petaninya menanam tanaman jagung pangan. Metode penentuan sampel dalam penelitian ini dilakukan menggunakan metode simple random sampling dengan metode rumus Parel, et al (1973). Berdasarkan rumus tersebut didapatkan jumlah sampel minimum adalah 36 orang dari 110 orang petani jagung yang menanam pada musim tanam Februari s/d Juni 2015. Dalam penelitian ini metode analisis data yang digunakan sesuai dengan tujuan penelitian adalah sebagai berikut:

\subsection{Tujuan Pertama: Menganalisis efisiensi alokatif penggunaan faktor - faktor produksi pada usahatani jagung di daerah penelitian}

Alat analisis yang digunakan untuk menjawab tujuan pertama dilakukan melalui dua tahap yaitu, dengan mengestimasi fungsi produksi dan analisis efisiensi alokatif sebagai berikut:

\section{a. Estimasi Fungsi Produksi}

Fungsi yang digunakan dalam penelitian ini adalah fungsi model Cobb-Douglas, yang dapat dituliskan sebagai berikut:

$$
\mathrm{Y}=\beta_{0} \mathrm{X}_{1}{ }^{\beta 1} \mathrm{X}_{2}{ }^{\beta 2} \mathrm{X}_{3}{ }^{\beta 3} \mathrm{X}_{4}{ }^{\beta 4} \mathrm{e}^{\mathrm{u}} \text {. }
$$

Dengan mentranformasikan fungsi model Cobb-Douglas tersebut ke dalam bentuk linear logaritma, maka model fungsi respon produksi jagung menjadi sebagai berikut

$$
\begin{aligned}
& \operatorname{LnY}=\beta_{0}+\beta_{1} \operatorname{Ln} X_{1}+\beta_{2} \operatorname{LnX}{ }_{2}+\beta_{3} \operatorname{LnX}_{3}+\beta_{4} \operatorname{LnX} X_{4} \\
& +\mathrm{u}
\end{aligned}
$$

Dimana :

$\beta_{0} \quad=$ Intersep $/$ Konstanta

$\beta 1 \ldots, \beta 6=$ Elastisitas produksi

$\mathrm{Y} \quad=$ Produksi jagung/Output $(\mathrm{Kg})$

$\mathrm{X} 1=$ Benih jagung hibrida $(\mathrm{Kg})$

$\mathrm{X} 2=$ Pupuk $(\mathrm{Kg})$

$\mathrm{X} 3=$ Tenaga Kerja (HKSP)

$\mathrm{X} 4 \quad=$ Luas Lahan $(\mathrm{Ha})$

$\mathrm{u} \quad=$ Kesalahan (disturbance terms)

$\mathrm{e} \quad=$ Bilangan natural $(\mathrm{e}=2,718)$

Kemudian dilanjutkan dengan analisis efisiensi alokatif untuk mengetahui tingkat efisiensi faktor-faktor produksi.

\section{b. Analisis Efisiensi Alokatif}

Efisiensi alokatif dapat dianalisis dengan cara membandingkan nilai produk marginal (NPMxi) dan harga input tersebut (Pxi). Secara matematis dapat dituliskan sebagai berikut:

$$
\frac{N P M_{X i}}{P_{X i}}=1 \text {. }
$$

Dimana :

$$
\begin{aligned}
N P M_{x i} & =P M_{X i} \cdot P_{y} \\
N P M_{x i} & =b_{i} \frac{Y}{X_{i}} \cdot P_{y}
\end{aligned}
$$


Keterangan:

$$
\begin{aligned}
& \mathrm{NPM}_{\mathrm{xi}}=\text { Nilai produk marginal faktor produksi } \\
& \text { ke-i } \\
& \text { PMxi = Produk marginal faktor produksi ke-i } \\
& \mathrm{b}_{\mathrm{i}} \quad=\text { Koefisien regresi } \mathrm{X}_{\mathrm{i}} \\
& \mathrm{X}_{\mathrm{i}} \quad=\mathrm{Rata}-\text { rata penggunaan faktor produksi } \\
& \text { jagung ke-i } \\
& \mathrm{Y}=\text { Rata }- \text { rata produksi jagung }(\mathrm{Kg}) \\
& \text { Pxi = Rata }- \text { rata harga faktor produksi } \\
& \text { jagung ke-i (Rp) } \\
& \text { Py = Rata }- \text { rata harga satuan hasil produksi } \\
& \text { jagung (Rp) }
\end{aligned}
$$

Jika $\frac{\text { NPMx }}{\text { Pxi }}>1$, maka input $\mathrm{x}$ belum efisien artinya penggunaanya terlalu sedikit pada tingkat harga yang berlaku. Jika $\frac{\mathrm{NPMx}}{\mathrm{Pxi}}<1$, artinya input $\mathrm{x}$ tidak efisien karena penggunaanya sudah terlalu banyak pada tingkat harga yang berlaku. Apabila NPMxi = Px, maka keuntungan yang diperoleh maksimum.

\subsection{Tujuan Kedua: Menganalisis tingkat produksi dan pendapatan petani pada usahatani jagung di daerah penelitian}

Analisis yang digunakan untuk menjawab tujuan kedua yaitu analisis secara deskriptif dengan membandingkan rata-rata tingkat produksi dengan data Badan Pusat Statistik Kabupaten Malang dan rata - rata hasil dari penelitian - penelitian terdahulu di sekitar Jawa Timur. Membandingkan pendapatan petani jagung di daerah penelititan dengan rata - rata hasil penelitian - penelitian terdahulu di sekitar Jawa Timur. Cara menganalisis tingkat pendapatan usahatani dilakukan dengan membuat tabel cash flow usahatani pada musim tanam pada saat penelitian.

\subsection{Tujuan Ketiga: Menganalisis faktor- faktor yang berpengaruh pada produksi dan pendapatan usahatani jagung di daerah penelitian}

Alat analisis yang digunakan untuk menjawab tujuan ketiga yaitu dengan analisis fungsi produksi dan analisis fungsi respon pendapatan sebagai berikut:

\section{a. Analisis Fungsi Respon Produksi}

Fungsi yang digunakan dalam penelitian ini adalah fungsi model Cobb-Douglas, yang dapat dituliskan sebagai berikut:

$$
Y=\beta_{0} X_{1}^{\beta 1} X_{2}^{\beta 2} X_{3}^{\beta 3} X_{4}^{\beta 4} X_{5}^{\beta 5} X_{6}^{\beta 6} e^{u}
$$

Dengan mentranformasikan fungsi model Cobb-Douglas tersebut ke dalam bentuk linear logaritma, maka model fungsi respon produksi jagung menjadi sebagai berikut:

$\operatorname{LnY}=\beta_{0}+\beta_{1} \operatorname{Ln} X_{1}+\beta_{2} \operatorname{Ln} X_{2}+\beta_{3} \operatorname{LnX}_{3}+\beta_{4} \operatorname{Ln} X_{4}$

$+\beta_{5} \operatorname{LnX} X_{5}+\beta_{6} \operatorname{LnX} X_{6}+\mathrm{u}$

Dimana :

$\beta_{0} \quad=$ Intersep / Konstanta

$\beta 1 \ldots, \beta 6=$ Elastisitas produksi

$\mathrm{Y}=$ Produksi jagung/Output $(\mathrm{Kg})$

$\mathrm{X} 1=$ Benih jagung hibrida $(\mathrm{Kg})$

$\mathrm{X} 2=$ Pupuk $(\mathrm{Kg})$

$\mathrm{X} 3=$ Tenaga Kerja (HKSP)

$\mathrm{X} 4=$ Luas Lahan $(\mathrm{Ha})$

X5 = Usia $(\mathrm{Th})$

X6 = Pengalaman Berusahatani (Th)

$\mathrm{u}=$ Kesalahan (disturbance terms)

$\mathrm{e} \quad=$ Bilangan natural $(\mathrm{e}=2,718)$

b. Analisis Fungsi Pendapatan

Analisis ini digunakan untuk menjawab faktor yang berpengaruh terhadap pendapatan usahatani padi secara matematis dapat dituliskan sebagai berikut:

$\mathrm{PDPT}=\beta_{0}+\beta_{1} \mathrm{PROD}+\beta_{2} \mathrm{BNH}+\beta_{3} \mathrm{PPK}+\beta_{4} \mathrm{TK}$

$+\beta_{5} \mathrm{LHN}+\beta_{6} \mathrm{LNN}+\mathrm{u}$.

Dimana :

$\beta 0=$ Intersep / Konstanta

$\beta 1 \ldots, \beta 6=$ Elastisitas produksi

PDPT $=$ Pendapatan $(\mathrm{Rp} / \mathrm{ha})$

PROD $=$ Produksi Jagung $(\mathrm{Rp} / \mathrm{ha})$

$\mathrm{BNH}=$ Biaya Benih $(\mathrm{Rp} / \mathrm{ha})$

PPK = Biaya Pupuk $(\mathrm{Rp} / \mathrm{ha})$

$\mathrm{TK}=$ Biaya Tenaga Kerja (Rp/HKSP)

LHN = Biaya Sewa Lahan per musim $(\mathrm{Rp} / \mathrm{ha})$

$\mathrm{LN}=$ Biaya Lainnya $(\mathrm{Rp} / \mathrm{ha})$

$\mathrm{u} \quad=$ Kesalahan (disturbance terms)

Dengan fungsi respon produksi dan fungsi pendapatan akan diperoleh jawaban pengaruh nyata atau tidak antara variabel bebas dan variabel terikat dengan melihat tingkat signifikansi masing - masing variabel yang diuji.

\subsection{Tujuan Keempat: Menganalisis pengaruh tingkat efisiensi yang dicapai petani terhadap tingkat pendapatan usahatani jagung di daerah penelitian}

Analisis untuk menjawab tujuan keempat, dianalisis dengan menggunakan analisis regresi linear berganda antara pendapatan usahatani dengan tingkat efisiensi alokatif masing - masing 
faktor produksi yang dicapai oleh petani. Secara matematis dapat dituliskan sebagai berikut:

$Y=\beta_{0}+\beta_{1} X_{1}+\beta_{2} X_{2}+\beta_{3} X_{3}+\beta_{4} X_{4}+u$

Dimana :

$\beta_{0} \quad=$ konstanta

$\beta_{1} \ldots \beta_{5}=$ koefisien regresi

$\mathrm{X}_{1} \quad=$ tingkat efisiensi benih masing masing petani

$\mathrm{X}_{2} \quad=$ tingkat efisiensi pupuk masing masing petani

$\mathrm{X}_{3} \quad=$ tingkat efisiensi tenaga kerja masing

- masing petani
$\mathrm{X}_{4} \quad=$ tingkat efisiensi luas lahan masing masing petani

$\mathrm{u} \quad=$ kesalahan (disturbance terms)

\section{Hasil Dan Pembahasan}

a. Analisis Efisiensi Alokatif Penggunaan Faktor - faktor Produksi

1). Analisis Fungsi Produksi

Hasil analisis regresi berganda fungsi produksi disajikan pada Tabel 1.

Tabel 1. Hasil analisis regresi linear berganda fungsi produksi

\begin{tabular}{|c|c|c|c|c|c|}
\hline \multicolumn{2}{|c|}{ Variabel } & Koefisien Regresi & $\mathbf{t}_{\text {hitung }}$ & Sig. & VIF \\
\hline (Constant) & & 7,005 & 9,455 & 0,000 & \\
\hline LnBenih & $(\mathrm{Kg})$ & 0,089 & 0,737 & 0,466 & 3,895 \\
\hline LnPupuk & $(\mathrm{Kg})$ & 0,024 & 0,211 & 0,834 & 2,587 \\
\hline LnTngKerja & (HKSP) & $0,397 *$ & 3,983 & 0,000 & 2,562 \\
\hline LnLahan & (Ha) & $0,390^{*}$ & 2,854 & 0,008 & 4,420 \\
\hline$F_{\text {hitung }}=42,74$ & & $\mathrm{R}^{2}=0,842$ & & & \\
\hline
\end{tabular}

Keterangan:

Variabel dependent $=$ Total Produksi $(\mathrm{kg})$

$\mathrm{F}_{\text {tabel }}(0,01) \mathrm{dfN} 1: 4, \mathrm{dfN} 2: 32=3,969$

$\mathrm{t}_{\text {tabel }}(0,01) \mathrm{df}: 32=2,738$

* = nyata pada taraf kesalahan $1 \%$

$\mathrm{F}_{\text {tabel }}(0,05)$ dfN1 $: 4, \mathrm{dfN} 2: 32=2,668$

$\mathrm{t}_{\text {tabel }}(0,05) \mathrm{df}: 32=2,036$

Dari hasil analisis fungsi produksi seperti pada Tabel 1, didapatkan variabel tenaga kerja dan lahan berpengaruh signifikan terhadap produksi usahatani jagung sehingga variabel tersebut yang akan diefisiensikan penggunaannya karena penambahan input faktor produksi tersebut mempengaruhi secara nyata terhadap produksi usahatani jagung di daerah penelitian.

\section{2). Analisis Efisiensi Alokatif}

Hasil analisis efisiensi alokatif dari ratarata penggunaan faktor-faktor produksi pada usahatani jagung disajikan pada Tabel 2. sebagai berikut.

Tabel 2. Analisis efisiensi alokatif penggunaan faktor-faktor produksi usahatani jagung di desa dengkol

\begin{tabular}{cccccccccc}
\hline Variabel & $\mathrm{Bi}$ & $\mathrm{Y}$ & $\mathrm{Py}$ & $\mathrm{X}$ & $\mathrm{Px}$ & $\mathrm{PMx}$ & $\mathrm{NPMx}$ & $\begin{array}{c}\text { NPMx } \\
/ \text { Px }\end{array}$ & Optimum \\
\hline $\begin{array}{c}\text { Tenaga } \\
\text { kerja }\end{array}$ & 0,397 & $5.859,4$ & 1.257 & 46,2 & 30.000 & 50,35 & $63.290,27$ & 2,1 & 97,46 \\
\hline Lahan & 0,390 & $5.859,4$ & 1.257 & 0,7 & 265.655 & $3.264,5$ & $4.103 .505,2$ & 15,4 & 10,81 \\
\hline
\end{tabular}

Dari Tabel 2. diatas diperoleh kesimpulan bahwa baik tenaga kerja maupun lahan samasama tidak efisien, hal tersebut ditunjukkan oleh nilai NPMx/Px $>1$. Penggunaan tenaga kerja masih tidak efisien. Rata - rata penggunaan tenaga kerja dalam satu hektar sebesar 46,2 HKSP masih terbilang kurang. Penggunaan tenaga kerja ini masih terlalu sedikit apabila dibandingkan dengan penggunaan tenaga kerja dari rata-rata hasil penelitian jagung terdahulu yang dilakukan oleh Arifah (2011) dan Munawaroh (2014) yaitu sebesar 148,61 HKSP. Penggunaan tenaga kerja usahatani jagung untuk daerah penelitian yang optimum adalah sebesar 97,46 HKSP. Sehingga penggunaan tenaga kerja perlu ditambah. Penggunaan tenaga kerja pada daerah penelitian paling besar digunakan pada saat proses panen, hal tersebut dikarenakan waktu panen dalam luasan lahan yang dimiliki petani dilakukan secara sekaligus atau serentak dalam 
satu hari agar dapat menghemat biaya yang dikeluarkan. Penggunaan lahan juga tidak efisien dengan NPMx/Px di lokasi penelitian yaitu 15,4. Hal tersebut menunjukkan penggunaan lahan masih terlalu sedikit. Rata - rata luas lahan usahatani jagung milik petani adalah sebesar 0,7 ha. Apabila dibandingkan dengan penelitian yang dilakukan oleh Faricha (2014) di Kabupaten Jombang dengan rata-rata penggunaan lahannya adalah sebesar $1 \mathrm{Ha}$. Penggunaan lahan yang optimum di daerah penelitian adalah sebesar 10,81 Ha. Perbedaan antara kondisi riil penggunaan lahan di Desa Dengkol dengan nilai optimum lahan yang didapat untuk usahatani jagung menunjukkan bahwa potensi usahatani jagung di Desa Dengkol sangat tinggi karena masih membutuhkan lahan yang cukup luas.

Apabila penggunaan optimum lahan tercapai dengan asumsi penggunaan faktor produksi lainnya bersifat konstan maka tingkat produksi yang diperoleh adalah kurang lebih 90 ton dalam satu musim tanam di Desa Dengkol. Akan tetapi, penambahan luas lahan yang dimiliki petani bukanlah hal yang mudah, karena petani yang umumnya mempunyai skala usaha yang relatif kecil terkendala akan harga tanah di Kabupaten Malang khususnya di daerah penelitian yang tergolong mahal dan lahan yang ada di daerah penelitian yang kurang sehingga dalam upaya meningkatkan pendapatan petani jagung dapat dilakukan dengan cara intensifikasi penggunaan lahan.

b. Analisis Tingkat Produksi dan Pendapatan Usahatani Jagung

Hasil analisis tingkat produksi dan pendapatan usahatani jagung disajikan pada Tabel 3. Dari data pada Tabel 3, dapat diketahui bahwa tingkat produksi/ha di daerah penelitian sejumlah $8.325 \mathrm{~kg}$ dengan harga jual Rp $1.275 / \mathrm{kg}$ dalam bentuk tongkol lebih tinggi dibandingkan tingkat produksi di Kabupaten Malang (BPS) dan tingkat produksi rata - rata hasil penelitian penelitian terdahulu yang dilakukan oleh Indroyono (2011), setiawan (2012) dan Faricha (2014). Tingkat pendapatan/ha sebesar Rp 4.892.030/ha, apabila dibandingkan dengan data dari hasil penelitian-penelitian terdahulu yang dilakukan oleh Indroyono (2011), setiawan (2012) dan Faricha (2014), pendapatan usahatani jagung di masih tergolong rendah. Hal ini dikarenakan perbedaan tingkat produktivitas di daerah masing - masing penelitian dan juga terjadi perbedaan sistem pemasaran yang dilakukan.

Tabel 3. Cash flow usahatani jagung per hektar dalam satu musim tanam

\begin{tabular}{|c|c|c|c|c|c|}
\hline Rincian & $\begin{array}{l}\text { Jumlah } \\
\text { fisik/ha }\end{array}$ & $\begin{array}{c}\text { Harga } \\
\text { Satuan (Rp) }\end{array}$ & $\begin{array}{c}\text { Nilai } \\
(\mathrm{Rp} / \mathrm{Ha})\end{array}$ & $\begin{array}{c}\text { Persentase } \\
(\%)\end{array}$ & $\begin{array}{c}\text { Data } \\
\text { Pembanding }\end{array}$ \\
\hline Produksi/Ha & $8.325 \mathrm{~kg}$ & 1.257 & 10.531 .490 & & $\begin{array}{c}8.183 \mathrm{~kg}^{*} \\
4.643 \mathrm{~kg}^{* *}\end{array}$ \\
\hline \multicolumn{6}{|l|}{ Biaya Variabel/Ha } \\
\hline 1. Benih & $20,18 \mathrm{~kg}$ & 45.675 & 895.257 & & \\
\hline \multicolumn{6}{|l|}{ 2. Pupuk } \\
\hline a. Urea & $353,07 \mathrm{~kg}$ & 1.900 & $611,079,11$ & & \\
\hline b. Phonska & $198,46 \mathrm{~kg}$ & 2.300 & $375.441,62$ & & \\
\hline c. ZA & $277,07 \mathrm{~kg}$ & 1.600 & $361.281,26$ & & \\
\hline d. Organik & $160,44 \mathrm{~kg}$ & 500 & $27.030,53$ & & \\
\hline 3. Tenaga Kerja & 65,70 (HKSP) & & $2.886 .904,76$ & & \\
\hline 4. Biaya lain-lain & & & $31.720,43$ & & \\
\hline Sub Total & & & $5.218 .313,17$ & 92,5 & \\
\hline \multicolumn{6}{|l|}{ Biaya Tetap } \\
\hline 1. Pajak Tanah & 0,70 ha & - & 265.655 & & \\
\hline 2. Penyusutan Alat & - & - & 62.212 & & \\
\hline 3. Biaya Angkut & - & - & 81.375 & & \\
\hline Sub Total & & & 409.242 & 7,5 & \\
\hline Total Biaya/Ha & & & 5.639 .460 & 100 & \\
\hline Pendapatan $(\pi)$ & & & 4.892 .030 & & $5.028 .143^{*}$ \\
\hline $\mathrm{R} / \mathrm{C}$ & & & 1,86 & & \\
\hline
\end{tabular}


Keterangan:

* = Data Rata - rata Hasil Penelitian Terdahulu di Jawa Timur

** = Data Badan Pusat Statistik Kabupaten Malang (2014)

Pada daerah penelitian menjual dalam bentuk tongkol dengan harga jual $\mathrm{Rp} 1.200-\mathrm{Rp}$ 1.300. Sedangkan data penelitian-penelitian terdahulu dalam bentuk pipilan kering dengan harga jual sebesar Rp 2.700 - Rp 2.900. Perbandingan antara bobot $(\mathrm{kg})$ jagung tongkol dengan jagung pipilan kering adalah sebesar 2:1. Artinya, apabila petani dapat menghasilkan kurang lebih $100 \mathrm{~kg}$ tongkol jagung kemudian dari jumlah tersebut akan mendapatkan kurang lebih $50 \mathrm{~kg}$ jagung pipilan kering. Selain perbedaan pendapatan disebabkan oleh perbedaan jumlah produksi dan sistem pemasaran, perbedaan pendapatan juga dapat disebabkan oleh total biaya yang digunakan dalam usahatani jagung.
Berdasarkan dari total rata-rata penerimaan per hektar dan total biaya per hektar yang dikeluarkan, diperoleh nilai $\mathrm{R} / \mathrm{C}$ ratio adalah sebesar 1,86 . Hal tersebut dapat menunjukkan bahwa usahatani jagung di Desa Dengkol menguntungkan dan layak dilanjutkan, karena nilai $\mathrm{R} / \mathrm{C}$ ratio lebih dari 1 .

c. Analisis faktor-faktor yang berpengaruh pada produksi dan pendapatan usahatani jagung di daerah penelitian

\section{1). Analisis Fungsi Respon Produksi}

Hasil analisis regresi linear berganda fungsi respon produksi disajikan pada Tabel 4 sebagai berikut:

Tabel 4. Hasil Analisis Regresi Linear Berganda Fungsi Respon Produksi

\begin{tabular}{lccccc}
\hline \multicolumn{1}{c}{ Variabel } & & Koefisien Regresi & $t_{\text {hitung }}$ & Sig. & VIF \\
\hline (Constant) & & 9,306 & 6,371 & 0,000 & \\
\hline LnBenih & $(\mathrm{Kg})$ & 0,051 & 0,421 & 0,676 & 4,212 \\
\hline LnPupuk & $(\mathrm{Kg})$ & $-0,011$ & $-0,100$ & 0,921 & 2,662 \\
\hline LnTngKerja & $(\mathrm{HKSP})$ & $0,442^{*}$ & 4,417 & 0,000 & 2,745 \\
\hline LnLahan & $(\mathrm{Ha})$ & $0,392^{*}$ & 2,812 & 0,009 & 4,875 \\
\hline LnUmur & $(\mathrm{Th})$ & $-0,496$ & $-1,629$ & 0,114 & 1,266 \\
\hline LnPnglaman & $(\mathrm{Th})$ & $-0,044$ & $-0,521$ & 0,606 & 1,314 \\
\hline$F_{\text {hitung }}=30,876$ & & $\mathrm{R}^{2}=0,861$ & & & \\
\hline
\end{tabular}

\section{Keterangan:}

Variabel Dependen $=$ Produksi $(\mathrm{kg})$

$\mathrm{F}_{\text {tabel }}(0,01) \mathrm{dfN} 1: 6, \mathrm{dfN} 2: 30=3,473$

$\mathrm{t}_{\text {tabel }}(0,01) \mathrm{df}: 30=2,749$

a) Tenaga Kerja

Penggunaan tenaga kerja berpengaruh positif terhadap produksi usahatani jagung pada $\alpha$ $=0,01$. Koefisien regresi sebesar 0,442 dapat menunjukkan bahwa setiap peningkatan penggunaan kerja sebesar $1 \%$ maka akan dapat meningkatkan produksi usahatani jagung rata rata sebesar $0,442 \%$.

Dari keadaan tersebut dapat diperoleh kesimpulan bahwa peningkatan jumlah tenaga kerja pada daerah penelitian hanya dapat meningkatkan produksi jagung dalam jumlah yang tergolong kecil. Oleh sebab itu, untuk meningkatkan produksi jagung selain menambah jumlah tenaga kerja, dapat dilakukan dengan cara meningkatkan produktivitas tenaga kerja.

$$
\begin{gathered}
*=\text { nyata pada taraf kesalahan } 1 \% \\
\mathrm{~F}_{\text {tabel }}(0,05) \text { dfN } 1: 6, \text { dfN2 }: 30=2,420
\end{gathered}
$$

\section{b) Lahan}

Penggunaan lahan berpengaruh positif terhadap produksi usahatani jagung pada $\alpha=$ 0,01 . Koefisien regresi sebesar 0,392 yang artinya bahwa setiap peningkatan luas lahan yang dimiliki sebesar $1 \%$ akan dapat meningkatkan produksi usahatani jagung rata - rata sebesar $0,392 \%$.

Luas lahan yang dimiliki petani menjadi faktor penting terhadap jumlah produksi jagung yang dihasilkan, semakin luas lahan yang dimanfaatkan untuk bercocok tanam jagung, semakin besar pula hasil produksi yang didapatkan oleh petani jagung di Desa Dengkol. Berdasarkan analisis, diketahui bahwa peningkatan luas lahan dapat meningkatkan produksi jagung di daerah penelitian. 
Ketidaktersediaannya lahan di daerah penelitian menjadi kendala dalam peningkatan produksi sedangkan rata - rata kepemilikan lahan petani jagung yaitu hanya 0,7 ha. Oleh sebab itu, peningkatan produksi jagung juga dapat dilakukan dengan intensifikasi penggunaan lahan milik petani melalui penggunaan sarana produksi benih serta pupuk yang baik dan optimal.

Tabel 5. Hasil Analisis Regresi Fungsi Pendapatan

\begin{tabular}{|c|c|c|c|c|}
\hline Variabel & Koefisien Regresi & $t_{\text {hitung }}$ & Sig. & VIF \\
\hline (Constant) & 13,773 & 4,372 & 0,000 & \\
\hline Produksi & $2,519^{*}$ & 13,777 & 0,000 & 2,227 \\
\hline Biaya Benih & $-0,260 * * *$ & $-1,921$ & 0,064 & 1,526 \\
\hline Biaya Pupuk $\quad(\mathrm{Rp} / \mathrm{ha})$ & $-0,421 *$ & $-3,795$ & 0,001 & 1,240 \\
\hline Biaya TenagaKerja (Rp/ha) & $-0,849 *$ & $-5,430$ & 0,000 & 2,303 \\
\hline Biaya Lahan $\quad(\mathrm{Rp} / \mathrm{ha})$ & $-0,066$ & $-0,562$ & 0,578 & 1,118 \\
\hline Biaya lainnya & 0,121 & 0,704 & 0,487 & 1,662 \\
\hline$F_{\text {hitung }}=37,473$ & & $=0,859$ & & \\
\hline
\end{tabular}

\section{Keterangan:}

Variabel Dependen $=$ Pendapatan $(\mathrm{Rp} / \mathrm{ha})$

* = nyata pada taraf kesalahan $1 \%$

$* * *$ = nyata pada taraf kesalahan $10 \%$

$\mathrm{F}_{\text {tabel }}(0,01) \mathrm{dfN} 1: 6, \mathrm{dfN} 2: 30=3,473$

\section{2). Analisis Fungsi Pendapatan}

Dari tabel 5 diatas diketahui bahwa $\mathrm{R}^{2}$ sebesar 0,859 yang artinya data variabel bebas yang digunakan didalam model dapat menjelaskan variabel terikatnya sebesar $85,9 \%$ sedangkan $14,1 \%$ sisanya dijelaskan oleh variabel lain yang tidak dimasukkan didalam model. Nilai F hitung sebesar 37,473 pada taraf kepercayaan $99 \% \quad(\alpha=0,01)$. Dari keenam variabel bebas yang diuji, didapat bahwa variabel biaya benih, biaya pupuk, biaya lahan berpengaruh negatif nyata, produsi berpengaruh positif nyata sedangkan biaya tenaga kerja dan biaya lainnya tidak terlihat pengaruh secara nyata terhadap tingkat pendapatan petani jagung. Biaya benih, pupuk, tenaga kerja berpengaruh negatif, sesuai dengan teori ekonomi apabila terjadi penambahan biaya makan dapat menurunkan pendapatan. Sedangkan produksi berpengaruh $\mathrm{t}_{\text {tabel }}(0,01) \mathrm{df}: 30=2,749$,

$\mathrm{t}_{\text {tabel }}(0,05) \mathrm{df}: 30=2,042$

$\mathrm{t}_{\text {tabel }}(0,10) \mathrm{df}: 30=1,697$

$\mathrm{F}_{\text {tabel }}(0,05) \mathrm{dfN} 1: 6, \mathrm{dfN} 2: 30=2,420$

positif sehingga dapat dikatakan semakin besar tingkat produksi yang dicapai semakin tinggi pendapatan yang diperoleh.

Biaya lahan dan biaya lainnya (biaya penyusutan alat dan biaya pengangkutan) tidak tampak pengaruh yang nyata terhadap pendapatan usahatani jagung di daerah penelitian, hal tersebut diduga disebabkan karena data antar responden yang kurang bervariasi sehingga dalam analisis ini belum dapat menyimpulkan pengaruhnya terhadap pendapatan usahatani.

\subsection{Tujuan 4: Analisis Pengaruh Tingkat Efisiensi Terhadap Tingkat Pendapatan Usahatani Jagung}

Hasil analisis pengaruh tingkat efisiensi terhadap tingkat pendapatan usahatani jagung disajikan pada Tabel 6. sebagai berikut:

Tabel 6. Pengaruh Tingkat Efisiensi yang Dicapai Peani Terhadap Pendapatan Usahatan Jagung

\begin{tabular}{lccc}
\hline \multicolumn{1}{c}{ Tingkat Efisiensi (NPMx/Px) } & Koefisien & $\mathbf{t}_{\text {hitung }}$ & Sig. \\
\hline Tenaga Kerja & 0,437 & 1,222 & 0,230 \\
\hline Lahan & $-0,093$ & $-0,359$ & 0,722 \\
\hline $\mathrm{F}_{\text {hitung }}=0,763$ & $\mathrm{R}^{2}=0,043$ & &
\end{tabular}

Keterangan:

Variabel bebas $=$ Pendapatan $(\mathrm{Rp})$

$\mathrm{t}_{\text {tabel }}(0,10) \quad=\mathrm{df}: 34=1,69092$

Lahan $=24,45(\mathrm{SD}=18,60)$

Tabel 6. menunjukkan tingkat efisiensi tenaga kerja dan lahan tidak memperoleh koefisien regresi yang signifikan sehingga
$\mathrm{F}_{\text {tabel }}(0,10)=\mathrm{dfN} 1: 2 \mathrm{dfN} 2: 34=2,47$

Tenaga Kerja $\quad=3,09(\mathrm{SD}=1,56)$

analisis ini tidak dapat menyimpulkan pengaruh tingkat efisiensi lahan dan tenaga kerja terhadap pendapatan usahatani jagung. Hal ini diduga 
dikarenakan variasi data tingkat efisiensi antar responden sangat kecil, yang ditunjukkan oleh SD nya < nilai rata - ratanya. Rata - rata tingkat efisiensi tenaga kerja adalah 3,09 $(\mathrm{SD}=1,56)$ dan lahan dengan rata - rata yaitu $24,45(\mathrm{SD}=$ $18,60)$.

\section{Kesimpulan}

Berdasarkan hasil analisis penelitian yang dilakukan, dapat disimpulkan sebagai berikut:

Pada tingkat harga yang berlaku saat penelitian, penggunaan faktor - faktor produksi pada usahatani jagung secara alokatif semuanya tidak efisien. Tenaga kerja dan lahan penggunaannya masih terlalu sedikit. Rata - rata penggunaan tenaga kerja di daerah penelitian 46,2 HKSP dan lahan 0,7 Ha.

Tingkat produksi usahatani jagung di daerah penelitian dengan rata - rata produksi senilai $8.325 \mathrm{~kg} / \mathrm{ha}$ tergolong tinggi dibandingkan dengan data dari BPS Kab. Malang dengan rata rata produksi senilai $4.643 \mathrm{~kg} / \mathrm{ha}$ dan dibandingkan dari data hasil penelitian penelitian terdahulu di Jawa Timur dengan rata rata produksi $8.183 \mathrm{~kg} / \mathrm{ha}$. Akan tetapi, tingkat pendapatan masih tergolong rendah, rata - rata pendapatan $\mathrm{Rp}$ 4.892.030/ha, sedangkan rata rata dari hasil penelitian - penelitian terdahulu di Jawa Timur yaitu Rp 5.028.143/ha.

Penggunaan tenaga kerja dan lahan berpengaruh positif terhadap produksi artinya penambahan tenaga kerja dan lahan di daerah penelitian dapat meningkatkan produksi jagung karena penggunaan tenaga kerja dan lahan masih sedikit dengan rata - rata penggunaan tenaga kerja 46,2 HKSP dan lahan 0,7 Ha. Pengeluaran biaya benih, biaya pupuk, dan biaya tenaga kerja berpengaruh negatif terhadap pendapatan artinya pengeluaran biaya-biaya tersebut dapat menurunkan tingkat pendapatan usahatani jagung. Sedangkan jumlah produksi berpengaruh positif artinya jumlah produksi dapat meningkatkan pendapatan usahatani jagung.

Tingkat efisiensi alokatif tenaga kerja dan lahan tidak dapat disimpulkan pengaruhnya terhadap tingkat pendapatan usahatani jagung dalam hasil analisis penelitian ini, dikarenakan data antar responden kurang bervariasi (Rata rata $\mathrm{TK}=3,09 ;(\mathrm{SD}=1,56) ;$ rata - rata lahan $=$ $24,45 ;(\mathrm{SD}=18,6))$.

\section{Daftar Pustaka}

[1]. Anggita (2014). Efisiensi Penggunaan Faktor-faktor Produksi pada Usahatani
Jagung Studi Kasus di Desa Bendosewu, Kecamatan Talun, Kabupaten Blitar.

[2]. Arifah, Eka. N. 2011. Analisis Efisiensi Ekonomi Penggunaan Faktor - Faktor Produksi Pada Usahatani Jagung Varietas Bisi-2 di Kabupaten Bantul. Skripsi. Universitas Sebelas Maret. Surakarta.

[3]. Badan Pusat Statistik. 2014. Kabupaten Malang dalam Angka 2014.

[4]. . 2015 a Keadaan Ketenagakerjaan Februari 2014.

[5]. . 2015 ${ }^{\mathbf{b}}$. Luas Panen, Produktivitas dan Produksi Tanaman Pangan Menurut Provinsi (Dinamis).

[6]. Faricha (2014). Analisis Keunggulan Komparatif Usahatani Jagung (Zea mays) di Kabupaten Jombang.

[7]. Indroyono (2011). Analisis Efisiensi Alokatif Penggunaan Faktor- faktor Produksi Jagung di Desa Sukolilo, Kecamatan Wajak, Kabupaten Malang.

[8]. Kementerian Perdagangan. 2012. Potensi Jagung, Upaya Meningkatkan Produksi dan Pemasaran Luar Negeri. Ditjen PEN/MJL/003/5/2012 Edisi Mei.

[9]. Munawaroh, Nikmatul Fitri, Endang S.R, Susi W.A. 2014. Analisis daya saing jagung di kabupaten grobogan Jawa tengah.

[10]. Parel, CP. et.al. 1978. Sampling Design and Procedures. A/D/C Asia Office. Tanglin.

[11]. Semaoen, Iksan 1992. Ekonomi Produksi Pertanian: Teori dan Aplikasinya.

[12]. Setiawan, Ryan.A.P. 2012. Analisis Efisiensi Alokatif Input Produksi Usahatani Jagung (Zea mays L.) Di Desa Kramat, Kecamatan Bangkalan, Kabupaten Bangkalan. Skripsi. Universitas Brawijaya. Malang.

[13]. Soekartawi. 2002. Analisis Usaha tani. Universitas Indonesia. Jakarta. 